LICENÇA CC BY:

Artigo distribuído sob os termos

Creative Commons, permite uso e distribuição irrestrita em qualquer meio desde que $o$ autor credite a fonte original.

\title{
DISCURSO E RESISTÊNCIA NA OBRA POÉTICA DE ELIANE POTIGUARA EM METADE CARA, METADE MÁSCARA
}

DISCOURSE AND RESISTANCE IN THE POETIC WORK OF ELIANE POTIGUARA IN METADE CARA, METADE MÁSCARA

DISCURSO Y RESISTENCIA EN LA OBRA POÉTICA DE ELIANE POTIGUARA EM
METADE CARA, METADE MÁSCARA

Neuza Maria Correa da Silva ${ }^{1}$

Dóris Helena Soares da Silva Giacomolli²

${ }^{1}$ Doutora em Educação Ambiental pela FURG. Docente do Instituto Federal SulRio-Grandense (IFSUL), Pelotas, RS, Brasil.

${ }^{2}$ Doutoranda em Letras pela Universidade Federal do Rio Grande (FURG), Rio Grande, RS, Brasil.

Resumo: Este artigo tem por intuito articular uma reflexão acerca de questões imanentes ao discurso exarado no livro Metade cara, metade máscara. Pretendemos acentuar as regularidades arquivadas nas formações discursivas que atravessam a fala de Eliane Potiguara, norteiam sua poesia e sua palavra em movimento, nos norteando pelos teóricos Michel Foucault e Eni Orlandi para, a partir da fala de Potiguara, observarmos a ordem discursiva que a interpela. Pretendemos observar em que sujeito ela se converte ao tomar posse da palavra e dar vazão ao viver dos povos indígenas brasileiros. Pela análise da referida obra, percebemos que Potiguara vem, por meio de seu discurso poético, autobiográfico ou em forma de escrita jornalística de informação, exaltar a determinação e a firmeza da luta dos povos originários.

Palavras-chave: Eliane Potiguara; Michel Foucault; Eni Orlandi; Discurso; Literatura indígena.

Abstract: This article provides some reflections on issues inherent to the discourse recorded in the book Metade Cara, Metade Máscara (Half Face, Half, Mask). Our aim is to accentuate the regularities filed in the discursive formations that characterize Eliane Potiguara's discourse, orienting her poetry and her word in movement, guiding us through the theorists Michel Foucault and Eni Orlandi to, through Potiguara's discourse, observe the discursive order that challenges her. We aim to observe what subject she is converted into when she takes possession of the word and gives vent to the life of the Brazilian indigenous peoples. Through the analysis of this work, it can be seen that whether through her poetic or autobiographical discourse, or her journalistic writing of information, Potiguara exalts the determination and firmness of the struggle of the indigenous peoples.

Keywords: Eliane Potiguara; Michel Foucault; Eni Orlandi; Speech; Indigenous literature. 
Resumen: Este artículo tiene como objetivo articular una reflexión sobre temas que son inmanentes en el discurso presentado en el libro Metade Cara, Metade Máscara. Se pretende enfatizar las regularidades archivadas en las formaciones discursivas que cruzan el discurso de Eliane Potiguara, guían su poesía y su palabra en movimiento, guiándonos por los teóricos Michel Foucault y Eni Orlandi para, desde el discurso de Potiguara, observar el orden discursivo que la desafía Tenemos la intención de observar en qué tema se convierte ella al tomar posesión de la palabra y dar rienda suelta a la vida de los pueblos indígenas brasileños. Del análisis de este trabajo, queda claro que Potiguara llega, a través de su discurso poético, autobiográfico o en forma de redacción de información periodística, a exaltar la determinación y la firmeza de la lucha de los pueblos originarios.

Palabras clave: Eliane Potiguara; Michel Foucault; Eni Orlandi; Discurso; Literatura indígena.

\section{Introdução}

A Análise de Discurso se interessa pela linguagem como maneira de significar, por homens falando (ORLANDI, 1999, p. 15), uma vez que a fala já é um evento discursivo. Esse trabalho examina o viés discursivo e a posição de sujeito de Eliane Potiguara que, com o acesso ao discurso em Metade cara, metade máscara (2004), toma a palavra. A escritora, recusando ao povo indígena o papel de objeto literário, torna-se, produzindo sentidos, sujeito na batalha de conservar sua cultura, num movimento de resistência contra quem quer calá-la: "Chega de matar minhas cantigas e calar a minha voz" (POTIGUARA, 2004, p. 36). Eliane Potiguara não perde de vista o lugar que vem ocupar como defensora da voz indígena, e vem a significar e significar-se, a partir da materialidade linguística utilizada para a produção dos enunciados. A indígena procura produzir sentidos sobre direitos de homens e mulheres indígenas no que se refere à racificação, à reificação, à discriminação, ao preconceito, à terra e ao território, entre outras questões que são constituídas nesses discursos. De dentro de uma ordem discursiva que intenta defender o direito do povo indígena e a se defender como sujeito de discurso, cria seu espaço e condições de autorrepresentação. A escritora fala em nome do grupo oprimido ao qual pertence, assim como por si mesma, como sujeito oprimido.

No intento de analisar a "fala atravessada por uma ordem simbólica", ou seja, o discurso de Eliane Potiguara por meio do qual ela se faz mediação entre os indígenas e o meio social em que vivem os brancos opressores, utilizaremos algumas noções de discurso de Michel Foucault.

No Collège de France, ao assumir a cadeira de seu antigo professor Jean Hyppolite, na disciplina História dos Sistemas de Pensamento, Michel Foucault produz um discurso literário. A partir dessa aula inaugural proferida por ele, obra por nós conhecida como A ordem do discurso (1996), passamos a perceber que, no discurso, é sistema de regras do qual a fala e o sujeito que dela decorre são elementos fundamentais à ordem do discurso. Nesse momento, nos interessa o eu do discurso na "narrativa" em Metade cara, 
metade máscara, e como ele se insinua sub-repticiamente no discurso ${ }^{1}$, para acentuar as regularidades arquivadas nas formações discursivas que atravessam a fala de Eliane Potiguara, pois que sua fala remete ao discurso, concebido como sistema de regras.

Foucault vem nos dizer, nesta aula, que o discurso não se descobre em um exclusivo ponto no qual surgem diversas ramificações, mas, inversamente, permanece e acontece de forma ininterrupta, cíclica e constante, em todas as relações, não existindo fora desse poder. No sentido de compreender as formas pelas quais os poderes ligam-se a determinados discursos, a fim de produzir efeitos de verdade, Foucault nos diz ainda que, materialmente, seja no plano oral ou escrito, o discurso é a fala. Mediante procedimentos de exclusão e controle, a fala converte o falante em sujeito do discurso. No plano escrito, mediante um procedimento de controle, Eliane se converte e passa de falante a sujeito de um discurso em que está em jogo a constituição de um determinado objeto do saber. Ao tomar posse da palavra se torna uma protagonista nativa no mundo indígena, dona da voz e linguagem. A autora problematiza a sua condição de sujeito da cultura de seus povos e dos resultados de uma inserção na cultura branca; dá vazão ao viver dos povos indígenas brasileiros; seja em forma poética, seja de forma de cunho autobiográfico, ou em forma de escrita jornalística de informação sobre a situação indígena, Potiguara, de uma posição-sujeito, interpelada ideologicamente, vem estabelecer a diferença entre o verdadeiro e o falso, entre o que vem sendo dito a respeito do indígena e o que ela pretende dizer. Vem para defender sua posição na ordem do discurso que até então havia sido negado pelo "princípio de controle e exclusão" a que se refere Foucault (1996).

O discurso, segundo Foucault, significa poder quando se presta a servir interesses, podendo ser aproveitado para marginalizar e discriminar.

O discurso - como a psicanálise nos mostrou - não é simplesmente aquilo que se manifesta (ou oculta) o desejo; é também aquilo que é o objeto do desejo; é visto que isto a história não cessa de nos ensinar - o discurso não é simplesmente aquilo que traduz as lutas ou os sistemas de dominação, mais aquilo, por que, pelo que se luta, poder do qual podemos nos apoderar, permitir a transubstanciação e fazer do pão um corpo. (FOUCAULT, 1996, pág. 10-11)

De acordo com Foucault, o discurso se refaz a cada enunciação:

\begin{abstract}
Uma cumplicidade primeira com o mundo fundaria para nós a possibilidade de falar deles, nele; de designá-lo e nomeá-lo, de julgá-lo e de conhecê-lo, finalmente, sob a forma da verdade, é o discurso ele próprio que se situa no centro da especulação, mas este logo na verdade, não é se não um discurso já pronunciado, ou antes, são as coisas mesmas ou os acontecimentos que se tornam insensivelmente discurso, manifestando o segredo de sua própria essência. $O$ discurso nada mais é do que a reverberação de uma verdade nascendo diante de seus próprios olhos; e quando tudo pode enfim, tomar a forma do discurso, quando tudo pode ser dito a propósito de tudo, isto se dá porque todas as coisas, tendo manifestado intercambiado seu sentido, podem voltar à interioridade silenciosa de consequências de si. (FOUCAULT, 1996, pág. 48-49)
\end{abstract}

Se o discurso é a reverberação de uma verdade surgindo diante de seus próprios olhos, isso nos disse Foucault, como podemos ler acima, é por meio dessa verdade vista por Eliane Potiguara que surgem os motivos pelos quais ela luta; imersas nesses fundamentos, estão suas ideologias subjacentes. Não há como manter a passividade 
quando vê a realidade diante de si: seu povo indígena, vítima contumaz de constantes incursões do homem branco, de obstinadas e insistentes invasões de suas terras e de políticas mal articuladas. $\mathrm{O}$ indígena tem sido finalidade do racismo, paciente e propósito do preconceito.

Ainda tendo como meta o discurso de Eliane Potiguara, nos interessamos pelo trabalho de Eni Orlandi, que nos diz em sua obra Análise de discurso, Princípios e Procedimentos, de 1999, que há uma polissemia em torno da noção de discurso que, ao invés de refletir a heterogeneidade que há na linguagem, intenta apagá-la, obedecendo a uma homogeneidade infligida pelo discurso da mundialização que valoriza um único sentido, que além de consensual, apaga, oprime e esfacela as diferenças. Segundo a autora, a língua não nos vem como um sistema abstrato e formal. Ela nos diz também que nem é o sujeito a fonte dos sentidos, nem esses sentidos são produzidos por ele, mas sim em outro lugar, anterior e externo a ele e só se tornam possíveis a partir de sua materialização na linguagem, "refletindo sobre a maneira como a linguagem está materializada na ideologia e como a ideologia se manifesta na língua" (ORLANDI, 1999, p. 16). Pensando em quais filiações ideológicas estão presentes nestes discursos, além dos sentidos pré-construídos que são atualizados por meio de uma memória discursiva, vemos que Orlandi afirma:

\footnotetext{
Segundo o mecanismo da antecipação, todo sujeito tem a capacidade de experimentar, ou melhor, de colocar-se no lugar em que o seu interlocutor 'ouve' suas palavras. Ele antecipa-se assim a seu interlocutor quanto ao sentido que suas palavras produzem. Esse mecanismo regula a argumentação, de tal forma que o sujeito dirá de um modo, ou de outro, segundo o efeito que pensa produzir em seu ouvinte. Este espectro varia amplamente desde a previsão de um interlocutor que é seu cúmplice até aquele que, no outro extremo, ele prevê como adversário absoluto. Dessa maneira, esse mecanismo dirige o processo de argumentação visando seus efeitos sobre o interlocutor. (ORLANDI, 1999, p.39).
}

Assim, Eliane Potiguara, colocando-se no lugar em que o seu interlocutor "ouve" suas palavras, procura produzir sentido tanto naqueles que espera que se postem ao seu lado na defesa dos povos indígenas, quanto nos que vêm sendo antagonistas nessa luta desde há vários séculos, quando começou o processo de colonização no nosso país.

A colonização, processo pelo qual o conquistador ocupou e dominou novas terras e seus originários habitantes, apresentou, no Brasil, características de massacre. Não podemos deixar de reconhecer a violência desse processo colonial em que se deu a aculturação indígena. Desde então, o povo indígena tem sido alvo de apagamento. Por não ser um fato recente, o aniquilamento exibe raízes profundas; o prejuízo permanece de modo sistêmico. Trazidos pela colonização e comprovados por mais de quatro séculos de exclusão, o preconceito está arraigado na sociedade branca, na qual ainda permanece. Barreto (2008) explica que "as pessoas têm uma imagem muito negativa da cultura indígena, e ainda mantêm sobre os índios aquela ideia do 'bom selvagem', que é puro, vive perto da natureza, e deve ser mantido lá." (BARRETO, 2008, 126). Há uma grande porção da sociedade que considera que devem ser mantidos lá, nas profundezas da selva, que ajudem a preservá-la, desde que não atrapalhem o desenvolvimento da 
sociedade branca, que não exijam sempre mais terras, que não prejudiquem a extração de riquezas materiais do subsolo e que não profiram discursos contra o progresso e contra o status quo.

Na polissemia de discursos há a intenção clara de se aniquilar o discurso indígena. A mundialização e o discurso hegemônico se tornam homogêneo na ânsia de extinguir, oprimir e esfacelar as diferenças.

E eis que surge a voz de Eliane Potiguara, assentada em posições ideológicas que estão em jogo no processo sócio histórico no qual as palavras são produzidas. Por meio de um fundo revisionista que averigua e pontua a tradição, ela tem como objetivo valorizar a cultura, as linguagens, os imaginários, as identidades e as memórias desse povo que até agora não tinha voz própria. Ao falar sobre a identidade coletiva, Eliane Potiguara, submetida a uma ordem ideológica que a interpela, causando significações, pretende não só valorizar a alteridade e o diferencial, mas também preencher espaços que silenciam. Por meio do discurso, solicita ser compreendida e interpretada.

A autora, de nome pessoal Eliane Lima dos Santos, toma a palavra sempre sabendo quem é, para evitar essa supressão do discurso indígena, chega para dizer e deixar marcado, que enquanto tiver o coração aceso, não morre a indígena que vive em si.

Cabe mencionar que não são fáceis os caminhos que todos temos que trilhar, mas esses caminhos são exponencialmente mais difíceis para aqueles que vivenciaram, e vivenciam, um histórico de violência, de silenciamento e de desapropriação cultural. Há poucas vantagens em ser indígena hoje, no Brasil, porque para ser indígena é necessária muita coragem, muita garra e instinto de sobrevivência e eles, mesmo assim, permanecem, resistem, ressurgem; gritam por espaços e para terem direito a serem diferentes, para clamar por sua cultura e seu modo de viver. De um lugar de fala daquela que conhece, que se viu desaldeada com toda a sua família, por imposição do homem branco, Eliane tenta resgatar a memória e a identidade indígenas; não na procura exata de corrigir o passado, mas como busca de construção de um novo presente, de uma identidade e do resgate das raízes, seja por meio do testemunho, da linguagem jornalística, da poesia, ou da evocação de lendas e mitos indígenas. Ao voltar-se para si própria e para o lugar ao qual pertence, reescreve suas memórias e a de seus ancestrais. A autora projeta-se, tornando-se peça fundamental para a produção e a fixação da memória dos grupos indígenas, não só dos indígenas Potiguara, mas de todas as nações indígenas do Brasil.

\section{O discurso de Eliane Potiguara}

"O discurso é efeito de sentido entre locutores" (ORLANDI, 1999, p.21), e é esse sentido que Eliane Potiguara vem espraiar em Metade cara, metade máscara, livro publicado no ano de 2004, pela editora Global. Qual o efeito de sentido da máscara? Diz-se que, em mitos amazônicos, a máscara tem um poder de transformar, tem o poder 
de cura. Metade cara, metade máscara é uma criação literária que tem essa função, de curar, de pretender transformar, trazer uma carga terapêutica, daquelas que pretende lançar longe as agonias que a autora carrega dentro de si, pois nos diz ela:

\begin{abstract}
Literatura Indígena e nativa vem das entranhas da Terra, é o grito sufocado dos que precisaram emudecer, explodindo no ar seu verbo colorido como se fora uma grande bolha de água cristalceleste. É a explosão dos séculos e a nova forma de pensar, agir e decidir. Deixem-me dizê-la, por favor! E creem em mim como a luz do sol, como a essência da alma. É a manifestação "apressada" da Identidade indígena, que por sua vez é a manifestação do Cosmo através da ancestralidade (POTIGUARA, 2004).
\end{abstract}

Ao se estender na leitura, o leitor percebe que o caráter dos fragmentos varia, vai de uma narrativa mítica de dois personagens, acontece por poemas e toma conhecimento dos relatos pessoais da autora, passando, a saber, que a escrita de Potiguara (testemunha direta e indireta) é vinculada às suas próprias memórias, mas também a uma memória coletiva. A partir deles, dos fragmentos, o leitor tem algumas informações sobre a genealogia da autora, que pertence a uma família de índios desaldeados da Paraíba, ponto primordial de suas indagações e de seu discurso:

Que faço com a minha cara de índia?/ E meus espíritos / E minha força / E meu Tupã / E meus círculos ?/ Que faço com a minha cara de índia? / E meu sangue / E minha consciência / E minha luta / E nossos filhos ?/ Brasil, o que faço com a minha cara de índia?/Não sou violência / Ou estupro / Eu sou história / Eu sou cunha / Barriga brasileira / Ventre sagrado / Povo brasileiro / Ventre que gerou / O povo brasileiro / Hoje está só ... / A barriga da mãe fecunda / E os cânticos que outrora cantava / Hoje são gritos de guerra / Contra o massacre imundo (POTIGUARA, 2004, p. 34-35).

O funcionamento de alguns processos de interdição discursiva vem, transversalmente, da tematização da problemática das primeiras nações por meio da história atemporal do "par-emblema" da família indígena, Jurupiranga e Cunhataí, em que os sujeitos poéticos representam seus ancestrais. Jurupiranga e Cunhataí adentram em um plano alegórico que elucida, simbolicamente, o decurso funesto da diáspora dos povos indígenas, que tiveram que partir, em fuga, depois de elementos trágicos, à semelhança da própria Eliane Potiguara e sua família, reduzidas a mulheres, que fugiram depois do assassinato do avô em uma luta por terras. Jurupiranga sonha o renascimento do povo ameríndio e se compõe com elementos da sociedade brasileira: "Percebeu a comunhão da nova e avançada tecnologia utilizada por alguns indígenas com as tradições indígenas, onde o diálogo mantido por jovens versus velhos era uma realidade" (POTIGUARA, 2004, p. 129). Jurupiranga tem um sonho visionário, que pode abranger o sonho dos sujeitos indígenas:

Os brancos diziam que estavam reconhecendo a dívida histórica que aquele país tinha para com os povos tradicionais e por isso tinham decidido - politicamente - aceitar, pacificamente, as demandas que os povos apresentavam para o exercício dos direitos indígenas. [...] Num sobressalto e num piscar de olhos, vislumbrou a universidade indígena lotada de jovens, futuros antropólogos, cientistas, historiadores, jornalistas, juristas, contadores de sua própria história. Viu bibliotecas inteiras recheadas de livros escritos pelos próprios indígenas, viu uma qualidade de vida nunca vista em toda sua vida. Mulheres indígenas eram respeitadas quando passavam nas cidadelas ao fazerem suas compras ou quando necessitavam de recursos médicos, educacionais, jurídicos. Os velhos eram venerados por todos. (POTIGUARA, 2004, p. 129) 
O casal é apartado pelo advento dos primeiros colonizadores e vaga cada um por seu caminho por quinhentos anos. Os dois sofrem a perda das tradições e sabem do desespero em que vivem os povos indígenas. "Jurupiranga e Cunhataí são dois personagens do texto Ato de amor entre povos que sobreviveram à colonização e poeticamente vão nos contar suas dores, lutas e conquistas. Esses personagens são atemporais e sem locais específicos de origem" (POTIGUARA, 2004, p. 30). O amor desse casal simbólico das primeiras nações é submetido às provações da separação devido às migrações forçadas, aos danos das guerras que ambos enfrentam na época dos colonizadores e no presente.

O discurso de Potiguara, a partir de uma memória discursiva, traz à tona conceitos de dominação e resistência. Para Orlandi, a memória, é "tratada como interdiscurso", que se define como "aquilo que fala antes, em outro lugar, independentemente." Desta forma, o que é chamado de "memória discursiva: o saber discursivo que torna possível todo dizer e que retorna sob a forma do pré-construído, o já-dito que está na base do dizível, sustentando cada tomada da palavra" (ORLANDI, 1999, p. 31); o sujeito torna suas as palavras de uma voz anônima que se produz no interdiscurso, apropria-se da memória que despontará das mais diversas formas em diferentes discursos outros. $\mathrm{O}$ discurso por meio do qual se pode lutar para transformar a realidade em que vivemos é a explicitação da sociedade em que vivem os homens e um meio pelo qual verbalizam a realidade em que se inserem. Potiguara se posiciona como sujeito e, como autora do texto, reflete conceitos, tenta produzir sentido como membro que é da sociedade indígena. Ela sopesa, também, o posicionamento do sujeito que encara o indígena do lugar em que ocupa, confortavelmente colocado em uma sociedade maior, culta e branca.

Recorda Potiguara que, em decorrência de um processo migratório compulsório de agrupamentos indígenas expulsos de suas terras, e da morte de seu bisavô, se desloca do Nordeste para o Sul-Sudeste do país, a família de Eliane Potiguara se vê compelida a morar na cidade aonde ela, em 1950, vem a nascer. O avô de Eliane Potiguara morre em decorrência de um crime que até hoje permanece impune, como a maioria dos crimes contra os indígenas:

Conta-se que índio X, pai das meninas Maria de Lourdes, Maria Isabel, Maria das Neves e Maria Soledad, por combater a invasão às terras tradicionais no Nordeste, foi assassinado cruelmente, segundo palavras de uns velhos que encontrei um dia. Amarraram-lhe pedras aos pés, introduziramIhe um saco à cabeça e o arremessaram ao fundo das águas do litoral paraibano. A família colonizadora inglesa $X$ ainda fez desaparecer muitos pais e avós de família. Quase 70 anos depois, a empresa X foi à falência e nunca se fez justiça a esses crimes organizados, objetivando interesses políticos e econômicos locais. (POTIGUARA, 2004, p. 24)

Metade cara, metade máscara, urdido pela combinação de reminiscências pessoais e memórias de família, faz ressurgir esses elementos da biografia evocada:

As filhas do índio $X$ e toda a sua família, amedrontadas, assim como outras famílias, migraram para Pernambuco, nordeste do Brasil. Em 31 de dezembro de 1928 nascia a pequena Elza, filha de Maria de Lourdes, fraquinha e enferma - tanto pelas condições de vida de sua família quanto por sua própria mãe ter somente 12 anos, uma menina ainda em formação, violentada sexualmente pelo colonizador. (POTIGUARA, 2004, p. 24) 
A viúva e suas quatro filhas foram obrigadas a deixar a aldeia e migrar para Pernambuco.

Pouco tempo depois toda a família migrava de novo para o Rio de Janeiro, num navio subumano que trazia os nordestinos para o sul do Brasil. Sem conhecer ninguém e completamente empobrecida, a família indígena permaneceu por uns tempos nas ruas. Quando Maria de Lourdes, índia mulher, analfabeta, paraibana, nordestina [...] conseguiu trabalho, se estabeleceu com a família numa área de prostituição, chamada Zona do Mangue, próxima à Estação Ferroviária da Central do Brasil, na Praça XI, propriamente à rua General Pedra. (POTIGUARA, 2004, p. 24)

O núcleo familiar da autora, que ficou órfã na primeira infância, é composto apenas de mulheres: a avó, "vítima da violação sexual praticada por colonos que trabalhavam para a família inglesa" (POTIGUARA, 2004, p. 27); a mãe, "Maria de Lourdes que se estabeleceu com a família em uma zona de prostituição, chamada zona do Mangue", uma tia e uma irmã. Mulheres subalternas, discriminadas em razão da etnia, da classe social, de gênero, elas sofrem todo tipo de desprezo da sociedade, mas resistem, cuidando sozinhas de sua prole, porque seus homens morrem ou desaparecem. Forçadas a viver numa sociedade que as discrimina, sem conseguir se inserirem de maneira adequada, elas se tornaram migrantes, tentando sobreviver, em condições miseráveis, nos guetos urbanos. O livro é dedicado e descreve a avó, Maria de Lourdes, estuprada aos 12 anos, que dá à luz Elza, a mãe de Eliane, e vem morar no Rio de Janeiro, na zona do Mangue, conhecida zona de prostituição. Indígena desaldeada, entendedora das plantas, contadora de histórias, monumento da resistência e da batalha dos povos indígenas, benzedora, curandeira, mulher que alcançou preservar parcialmente o saber antigo, mesmo vivendo fora de sua aldeia e longe de seu povo, transmitiu à neta "os laços com os ancestrais, a cosmologia e a herança espiritual" (POTIGUARA, 2004, p. 26)

Potiguara conta que conseguiu, ainda que tardiamente, ter acesso à educação. Formou-se professora primária. Em 1978, casou-se com o cantor e compositor Taiguara². Formou-se em Letras e começou a frequentar o meio cultural do Rio de Janeiro. Começou a escrever poesia e a publicar suas obras. É de 1975 o poema "Identidade indígena", primeiro poema escrito por uma mulher indígena em língua portuguesa.

Indígena criada na zona urbana, não esqueceu suas raízes e decidiu retornar a Recife. Eliane tomou consciência da urgência do momento político ao retornar ao seu lugar de origem. Adotou para si o etnônimo indígena Potiguara, referente à etnia a qual pertence, os Potiguaras, um grupo indígena que habita parte da região Nordeste, de origem tupi, da família linguística tupi-guarani. Diz Antonio Machado3: "- Golpe a golpe, passo a passo, caminhante, não há caminho... O caminho é feito ao andar." Aí, na aldeia dos antepassados, se iniciou o caminho de Eliane Potiguara, seu contato com os indígenas que permaneceram, pôde conhecer as mulheres indígenas que testemunhavam em suas peles e rugas o sofrimento que causava a violação dos povos indígenas, o que despertou nela um sentimento ancestral do coletivo. Assim, desse retorno, percebeu a interpelação de uma verdade que encontrou eco em si e se deu o início da segunda etapa de seu diálogo com as mulheres indígenas. Pensava, já nessa época, na organização 
e na articulação das mulheres indígenas. Poeta, professora e militante, se engajou na defesa da causa indígena e vem nos dizer da posição que ocupava a mulher indígena nas tribos originárias. Antes do processo de escravidão, noz diz ela, "historicamente, a mulher indígena tinha o mesmo papel de decisão que os pais, maridos e irmãos. A sua palavra era a palavra final para decidir" (POTIGUARA, 2004, p.56). Com a "conquista" houve uma coisificação dessa mulher indígena. A conscientização da condição subalterna das mulheres indígenas a levou a se engajar na luta pela estruturação do movimento indígena em escala nacional e internacional:

Fez o retorno ao inconsciente coletivo, visitando nações indígenas e perseguindo, sem medir esforços, a verdadeira história da sua tão sacrificada, marginalizada e racificada família migrante do nordeste brasileiro. Visitou as terras imemoriais de sua mãe, de sua avó paraibana, de seus ancestrais espirituais. Ali sentiu a essência da existência humana, o seu cordão umbilical queimava e seus pés não andavam. (POTIGUARA, 2004, p. 27)

Ainda que poeta e escritora desde os anos de 1970, Metade cara, metade máscara é o primeiro livro da autora. Os discursos da escritora indígena são mais que enunciados formulados; têm força criadora que denuncia, que não se cala. Ao pronunciar o enunciado, se posiciona deixando ressurgir as vozes ancestrais, as memórias adormecidas em si. Participou de diversas ONGs, registrando e denunciando a situação etno-histórica das mulheres indígenas:

Fui muito feliz neste encontro comigo mesma e com a escritora, porque antes já havia incorporado inconscientemente a sabedoria de minha mãe, minhas tias indígenas e principalmente minha avó, Maria de Lourdes, filha do guerreiro indígena desaparecido, no início do século XX, refletido no que conto no início do livro. Sou feliz porque aprendi esses conceitos acima com elas, mesmo que elas estivessem fora de suas terras tradicionais. Elas foram enxotadas de suas terras, mas os valores, os conceitos, os princípios, a cosmologia jamais, em tempo algum, foram dizimados pelo colonizador. (POTIGUARA, 2004, p 89)

Denuncia que, após a chegada do branco, ela, a mulher indígena, tem sofrido abuso sexual. Ocorre, hodiernamente, tráfico de mulheres e mão de obra escrava: "Com a chegada dos estrangeiros, a mulher passou à retaguarda e permanece até hoje servindo de mão de obra escrava, ou submetendo-se à neocolonização como objeto sexual e descartável" (POTIGUARA, 2004, p.56).

Usando recursos da narração oral indígena com relatos do quadro referente à vida indígena, Potiguara denuncia a violação dos direitos humanos das mulheres indígenas que se têm conduzido às mãos de homens corruptos:

[...] haja vista centenas delas saírem de suas casas para a insegurança das cidades próximas... Isso constitui tráfico de mulheres. As mulheres indígenas também vão trabalhar como operárias mal remuneradas ou nas grandes plantações dos latifundiários, num sistema de cativeiros, trocando seu trabalho por latas de sardinhas. (POTIGUARA, 2004, p. 29)

Os brancos as seduzem por um prato de comida, por programas, promessas eventuais: "Outras vezes vão morar com homens sem caráter que as transformam em objeto de cama e mesa, submetidas a agressões físicas e parindo dezenas de filhos, para viver, miseravelmente, nas casas de palafitas da Amazônia." (POTIGUARA, 2004, pp. 29-30) 
Potiguara vem articular a história e a memória do ponto de vista da mulher seduzida e abandonada, vem nos falar sobre o desastre que advém do "desencontro" entre o colonizador e sua presa fácil, a mulher indígena:

\begin{abstract}
Uma mulher indígena Potyguara me contou um dia, em 1989: "Eu estava em casa sozinha, cozinhando; entrou um homem-peixe em minha casa e me tomou o espírito e partiu. Nunca mais o vi, mas sempre ia à beira-mar esperar por ele". Os dias se passaram, os meses, os anos... A mulher estava louca e velha. Havia passado toda uma vida e a velha esperava seu homem-peixe, desde que acontecera aquele incidente. A menina-moça estava em casa sozinha, entrou um colonizador local inescrupuloso nos anos 1940, a violentou sexualmente e fugiu... O desastre à mente daquela criança foi tamanho que o universo cultural foi completamente confundido, tornando-a uma criança - mulher - velha maltrapilha e louca! Quantas histórias dessa natureza teremos? (POTIGUARA, 2004, p. 44-45)
\end{abstract}

Porque o discurso consente que as ideologias se corporifiquem, surge na voz da Eliane Potiguara a denúncia da grave situação dos humilhados, da reificação das mulheres e da coisificação das crianças indígenas, da posição discriminatória e ofensiva que ocupam os indígenas no Brasil:

Vi um indiozinho escorrendo no bueiro. A metade de seu corpo superior debruçava-se sobre o meio-
fio da rua e a outra parte jazia cansada, escorrendo pelo esgoto urbano. Imediatamente, lembrei-me
do quadro de Salvador Dali, retratando um relógio de pulso descontraído em sua forma original,
mas reconstruído de forma que o relógio obedecesse às formas roliças do punho humano. Me
vieram à cabeça diversas imagens derretidas deste pintor surrealista, desconstruidor de formalidade
e convencionalidade sociais, políticas e humanas. Mas o indiozinho estava lá, derretendo, e eu tive
vontade de me derreter junto com ele pelo ralo planetar, mas não pude. Seria covardia de minha
parte! O menino de 10 anos, um indiozinho urbano, desse tipo que a intolerância e o paternalismo
sociais ignoram e invisibilizam, compunha o triste quadro da miséria humana. E se sua mãe pestanejar
pelos direitos humanos, como alimentar-se pelo menos, o paternalismo analisará: quem mandou
sair de sua aldeia, quem são seus pais, seus avós, nós não lembramos dessas histórias?! De vítima
do processo social e racial passa a oportunista. Essa índia não pôde ficar na sua aldeia e esperar o
"Paralelo 11 "12, versão 2004, ela fugiu antes! (POTIGUARA, 2004, p. 93-94)

De acordo com seu discurso em Metade cara, metade máscara tornou-se ativista, ao mesmo tempo em que busca proteger os direitos para os indígenas, busca seu lugar discursivo; tornou-se conselheira do Impbrapi, Instituto Indígena de Propriedade Intelectual, bem como Coordenadora da Rede de Escritores Indígenas na Internet. Recebeu, em 1996, o título de "Cidadania Internacional", concedido em 1996; o título de "Cidadania Internacional", concedido pela organização filosófica Iraniana Baha'i4 , que trabalha pela implantação da Paz Mundial. Foi premiada pelo Pen Club da Inglaterra pelo seu livro A Terra é a Mãe do Índio. Foi indicada, por seu trabalho como ativista, como representante do Brasil na campanha "Mil Mulheres Para o Prêmio Nobel da Paz 2005". Apesar de o discurso ser controlado, ela atreveu-se a desafiar aqueles que o controlam e participou, durante anos, da elaboração da "Declaração Universal dos Direitos Indígenas", na ONU em Genebra; viajou pelo mundo inteiro para participar de fóruns internacionais, em defesa dos direitos dos indígenas e das mulheres, lutando pela aprovação da "Declaração dos Direitos dos Povos Indígenas", aprovada na ONU no dia 13 de setembro de 2007, em Nova Iorque. Agindo incansavelmente, Eliane Potiguara preocupa-se, nomeadamente, com as mulheres indígenas, pois que essas se acham em 
permanente vulnerabilidade social. Foi nomeada uma das 10 mulheres do ano em 1988, pelo Conselho das Mulheres do Brasil, por ter criado o GRUMIN. Em 1978, fundou e é coordenadora do "Grupo Mulher-Educação Indígena" (Grumin), grupo de mulheres indígenas/Rede de Comunicação Indígena.

Se, por meio do exercício da fala, produzimos sujeito e sentido, Eliane Potiguara, submetida ao processo histórico e ideológico, percebe que urge falar e tornar-se sujeito e denuncia as invasões das terras indígenas, os assassinatos dos indígenas, expressando-se em forma de poesia: "Em 18 de abril de 1997, o líder indígena Marçal Tupã-y, assassinado em 25 de novembro de 1983, esteve nas terras do Sul do Brasil e disse: Eu não fico quieto não../Eu reclamo...Eu falo.../Eu denuncio." (POTIGUARA, 2004, p. 47). Aponta a urgência da demarcação de terras: "As terras indígenas devem ser definitivamente demarcadas como garantia da integridade física, social, cultural, econômica e psicológica dos povos indígenas." (POTIGUARA, 2004, p. 54). Não esquece que o país não considera a questão do território indígena como prioridade:

A demarcação das terras indígenas nunca foi uma prioridade governamental. Uma política que garantisse e respeitasse os povos indígenas como unidades sociopolíticas e culturais distintas deveria ser uma prioridade como respeito histórico. Nunca se realizou, na prática, uma política voltada aos interesses e projetos econômicos de auto sustentação propostos pelos indígenas, baseados em sua biodiversidade com segurança para a saúde, educação, agricultura e direitos humanos, considerando sua cultura diferenciada. (POTIGUARA, 2004, p. 44)

Seu discurso é de denúncia, de desespero, quando aponta:

Muitas famílias indígenas foram separadas pelas invasões estrangeiras. Invasões do passado, invasões do presente, invasões do futuro. No passado, as frentes de expansão econômica, as frentes missionárias, as frentes de atração eram as causas das transformações sociais das populações indígenas. (POTIGUARA, 2004, p. 23)

A autora se constitui sujeito e produz sentido querendo modificar a realidade que faz do indígena culpado e do branco inocente: "Nós tínhamos nossas terras e fomos acuados para as cidades! Não somos culpados. De vítimas, passamos a ser discriminados e oportunistas." (POTIGUARA, 2004, p. 49). Ou quando explica o que significa a terra para os indígenas, não posse, não status, não riqueza:

Um território não é apenas um pedaço ou vastidão de terras. Um território traz marcas de séculos, de cultura, de tradições. É um espaço verdadeiramente ético, não é apenas um espaço físico como muitos políticos querem impor. Território é quase sinônimo de ética e dignidade. Território é vida, é biodiversidade, é um conjunto de elementos que compõem e legitimam a existência indígena. Território é cosmologia que passa inclusive pela ancestralidade. (POTIGUARA, 2004, p. 105)

Potiguara denuncia o arrendamento de terras indígenas, a violência e os assassinatos envolvidos nesse processo, as consequências da usurpação do território para a constituição identitária e a negação de direitos para esses grupos.

O resultado desse efeito de sentido entre os interlocutores a transforma em presa a ser caçada, aquela que precisa dizer não: "Não à morte das famílias, não à perda da terra, não ao fim da identidade." (POTIGUARA, 2004, p. 64), e a se defender a si e aos povos indígenas, enquanto se justifica: "Não somos marginais das famílias, somos 
marginais das cidades, marginais das palhoças" (POTIGUARA, 2004, p. 60). Em virtude de noticiar arbitrariedades e combater injustiças, chegou a ser ameaçada de morte, razão pela qual intervieram em defesa de sua vida o Pen Clube da Inglaterra; a organização internacional Escritores na Prisão, que defendiam os Direitos Humanos em seus países; e a Agência de Imprensa Indígena (Aipin).

O discurso possui uma imensa força que pode ser usado contra o poder dominante e, então, precisa ser calado, ignorado ou reprimido porque representa perigo; pode abalar e causar medo às estruturas que sempre estiveram consolidadas.

Tudo se passa como se tivessem querido apagar até as marcas da irrupção nos jogos do pensamento e da língua. Há sem dúvida em nossa sociedade e, imagino em todas as outras, mas segundo um perfil e facetas diferentes, uma profunda logo fobia, um espécime de temor surdo destes acontecimentos, desta massa de coisas ditas, do surgir de todos estes enunciados, de tudo que possa haver aí de violento, de descontínuo, de combativo, de desordem, também, e de perigoso deste grande zumbido incessante e desordenado do discurso. (FOUCAULT, 1996, p. 50).

Quando alguém ousa se pôr contra os interesses dos poderosos, se apossar do discurso, começa a ser considerado perigoso, persona non grata, arremessando contra os interesses do status quo, que se esforça para se preservar. Eliane Potiguara enuncia algo mais que nomear ou apontar posições, e por isso ameaça o bem-estar de poderosos e passa a ser perseguida:

Sofreu humilhações públicas, ameaças de morte, extorsões, inclusive difamações em jornais de nome e locais, sofreu abuso sexual, prejudicando sua imagem moral, afetando seu trabalho, seu lado psicológico e de seus filhos. Para não prejudicar a imagem histórica, política e social de um povo, teve que calar na época, sendo levada pela Polícia Federal à frente de seus filhos como se fora uma assassina, teve que depor na Procuradoria do Estado, época do Governo de Fernando Collor, e retirar-se, constituindo assim um ato de respeito e desapego à história desse povo [...]. (POTIGUARA, 2004, p. 27)

Para o filósofo francês, Michel Foucault, o discurso é:

Um bem - finito, limitado, desejável, útil - que tem suas regras de aparecimento e também suas condições de apropriação e de utilização: um bem que coloca, por conseguinte, desde sua existência (e não simplesmente em suas "aplicações práticas"), a questão do poder; um bem que é, por natureza, o objeto de uma luta, e de uma luta política. (FOUCAULT 2007, p. 136-137)

Diz-nos o estudioso que ninguém apreende o poder, mas podemos praticá-lo, visto que ele somente é compreendido como um conjunto de relações de força, que se manifestam em ocasiões especiais nos movimentos históricos e na própria história.

Eliane Potiguara está profundamente inserida nas questões de poder, utiliza-se do discurso como sua arma de luta. Como esse jogo é perigoso, sofre as consequências:

Os danos morais, como difamação nos jornais da Paraíba, difamação local entre o povo indígena e o povo da cidadezinha, intrigas, discórdias, violência moral, psicológica, abuso sexual, enormes prejuízos ao trabalho do Grumin10, prejuízos pessoais, e financeiros, por conta de minha desestabilização emocional e física, me fizeram parar por quase uma década: realmente eu não aguentei o peso da dor moral e espiritual que me expôs à frente de meus próprios filhos, à frente de um povo que eu tentava parcerizar em uma luta pelos direitos humanos, à frente das organizações indígenas e indigenistas, feministas e outras que bem ou mal souberam dessa arbitrariedade. [...] Logo depois, meu nome foi notificado ao lado do nome do jornalista Caco Barcellos, no Jornal Nacional, na TV Globo, numa lista de "marcados para morrer". Caco Barcellos havia denunciado a 
Rota 6611 em São Paulo. Foi um susto avassalador e vivi um estado de horror, pois eu não sabia de onde partira essa ação e quem era o inimigo. Ele não tinha cara, não tinha nome. Era uma força contrária às minhas ideias, ao meu ideal. Naquele ano, meus filhos não passaram de ano na escola, também ficaram traumatizados e enfermos e a "insensibilidade" não se dá conta do mal que faz ao semelhante. (POTIGUARA, 2004, p. 109-110)

Do objeto de luta, dessa luta política inserida em seu discurso, desse conjunto de signos que expressava seu pensamento, surgiram severas consequências, que foram difíceis de suportar, ela passou por intensos terrores, mas, mesmo assim, conseguiu resistir e continuar sua luta.

\section{Conclusão}

Orlandi não considera o sujeito como a fonte dos sentidos que são, por sua vez, produzidos em outro lugar, anterior e externo a ele, "refletindo sobre a maneira como a linguagem está materializada na ideologia e como a ideologia se manifesta na língua" (ORLANDI, 1999, p. 16). Já que discorrer sobre discurso é raciocinar em termos de ideologia, de política, do poder que domina, daqueles que se subvertem ao poder dominante e em termos de pronunciamentos praticados pelo e contra o status quo, percebemos que Potiguara, instituindo e edificando um mundo em significado, vem falar, procurando a origem nas suas ideologias e nos discursos ideológicos de outros, os de seus antepassados.

A autora de Metade cara, metade máscara se pronuncia contra o discurso dos poderosos e por esse motivo foi perseguida e vilipendiada, mas até hoje se mantém ativista pelas causas dos direitos indígenas. De sua posição de indígena, estabelece um diálogo com outros lugares de fala, produz linguagem e se reproduz nela. Potiguara, tomando posse do discurso polêmico, didático, poético, jornalístico e autobiográfico e imbuindo-se do pensamento crítico necessário a esse processo e constituindo-se dele para sua prática, recupera aspectos históricos e procura sua significação do mundo.

\section{Referências}

BARRETO, P. C. da S. Os significados do racismo e do anti-racismo para os negros e indígenas. In: BARRETO, P. C. da S. Múltiplas Vozes - Racismo e Anti-Racismo na Perspectiva de Universitários de São Paulo. Salvador: EDUFBA, 2008, p. 91-158.

CARVALHO, J. B. de. Identidade e discriminação da população indígena. In VENTURINI, G.; et al. (orgs) Racismo no Brasil. Percepções da discriminação e do preconceito racial no século XXI. São Paulo: Editora Fundação Perseu Abramo, 2005, p.119-123.

FOUCAULT, M. A ordem do discurso. São Paulo: Loyola, 1996.

FOUCAULT, M. A Arqueologia do Saber. 7. ed. Rio de Janeiro: Forense Universitária, 2007. 
ORLANDI, E. Análise de discurso. Princípios e Procedimentos. Pontes: Campinas, 1999.

POTIGUARA, E. Metade cara, metade máscara. São Paulo: Global, 2004.

SOUZA, P. de. Análise de Discurso. Florianópolis: UFSC, 2014.

Artigo recebido em: 17/03/2019

Aprovado em: 22/07/2019

\section{Contato para correspondência:}

Dóris Helena Soares da Silva Giacomolli. E-mail: dorishssg@gmail.com

\section{Notas}

1 Gostaria de me insinuar sub-repticiamente no discurso que devo pronunciar hoje e nos que deverei pronunciar aqui, talvez durante anos. Em vez de tomar a palavra, gostaria de ser envolvido por ela e levado bem além de todo começo possível. (FOUCAULT, 1996, p. 6).

2 Taiguara, militante comunista, uruguaio de origem Charrua, que teve uma bemsucedida carreira na música popular brasileira, sobretudo nos anos 1960 a 1970, mas foi duramente perseguido pela ditadura. Foi o compositor com o maior número de canções censuradas na época da ditadura, se autoexilou em Londres. Voltou para o Brasil em 1975 e gravou o álbum Imyra, Tayra, Ipy; o LP foi recolhido das lojas, para nunca mais ser reeditado. Taiguara se exilou novamente.

3 Antônio Machado: Poeta espanhol (1875-1939)

4 A Fé Bahá'í é uma religião que surgiu na Pérsia, hoje Irã, em 1844. Possui suas próprias leis e escrituras sagradas que se baseiam nos ensinamentos de Baha'u'llah e não possui rituais, cultos, cleros e dogmas. Segundo os ensinamentos da fé Bahá'i, o propósito humano é aprender a conhecer e a amar a Deus por meio de métodos como orações, reflexões e ajuda aos outros. Os textos bahá'ís enfatizam a igualdade essencial dos seres humanos e a abolição de todos os tipos de preconceito. A humanidade é considerada essencialmente una, embora diversificada; esta diversidade de raça e cultura é considerada merecedora de apreciação e tolerância. Doutrinas de racismo, nacionalismo, castas e classes sociais são impedimentos artificiais da unidade. 